Research article

\title{
POST-MORTEM ESTIMATION OF TIME OF DEATH OF DOGS BASED ON MEASUREMENTS OF KIDNEY TEMPERATURE IN COMPARISON WITH RECTAL TEMPERATURE
}

\author{
LISTOS Piotr ${ }^{1}$, GRYZINSKA Magdalena ${ }^{2 *}$, PIORKOWSKI Jacek ${ }^{1}$, TERESINSKI \\ Grzegorz $^{3}$, BUSZEWICZ Grzegorz ${ }^{3}$, CHAGOWSKI Wojciech ${ }^{3}$, NOZDRYN- \\ PLOTNICKI Zbigniew ${ }^{1}$, LOPUSZYNSKI Wojciech ${ }^{1}$
}

${ }^{1}$ Department of Pathological Anatomy, University of Life Sciences, Lublin, Poland;

${ }^{2}$ Department of Biological Basis of Animal Production, University of Life Sciences, Lublin, Poland;

${ }^{3}$ Department of Forensic Medicine, Medical University of Lublin, Lublin, Poland

(Received 23 July; Accepted 13 November 2015)

\begin{abstract}
The subject of the study were dogs divided into two groups according to body weight: up to $10 \mathrm{~kg}$ and from $10 \mathrm{~kg}$ to $30 \mathrm{~kg}$. The aim of the study was to determine the dynamics of the post-mortem decrease in rectal and kidney temperature. The temperature was measured on both sites at the same time using a thermometer connected to a computer, under constant environmental conditions of the necropsy room. In these animals, a higher temperature in the kidneys persisted for the duration of the study. Comparative analysis between mean differences in kidney and rectal temperature in small and large dogs showed the greatest temperature amplitude in the group of small dogs, both for the kidney and the rectum. The greatest decrease in temperature, $1.2^{\circ} \mathrm{C}$, was noted for the kidney in small dogs between 4 and 6 hours after death. Analysis of the dynamics of the decrease in kidney and rectal temperature for both weight groups combined, and the difference in temperature between the kidney and the rectum in the time intervals analysed showed that in the first two hours the difference between kidney and rectal temperature did not exceed $0.5^{\circ} \mathrm{C}$. Two hours after death the difference in temperature between the two measurement sites was about $0.5^{\circ} \mathrm{C}$ after which time dropped below $0.5^{\circ} \mathrm{C}$.
\end{abstract}

Key words: signs of death in animals, time of death of animals, veterinary forensics

\section{INTRODUCTION}

Determining the time that may have passed from the moment a human being dies up to the discovery of the body is often an important responsibility for a physician appointed as an expert by law enforcement agencies [1,2]. This question is of great legal significance in both criminal and civil law. In the first case, the expert's opinion

\footnotetext{
*Corresponding author: e-mail: magdalena.gryzinska@up.lublin.pl
} 
makes it possible to verify witness testimony and various versions of the event, e.g. to assess the reliability of suspects' alibis. An example of implications for civil law is when the time of death determines whether there is an obligation arising from an insurance contract. In the case of death of related individuals, the order of their deaths can determine the order of inheritance [3-6].

Forensic medicine deals exclusively with issues related to the life and death of human beings under positive law. In contrast, veterinary forensics covers a much broader range of activity and deals not only with the life and death of animals, but also questions of their sale and infectious diseases in animals, with particular focus on zoonoses and hygiene of animal products. A veterinarian appointed to give an opinion in veterinary cases appears as an expert before the appropriate judicial bodies [7-10]. Veterinary forensics is a science covering all matters associated with veterinary protection of animals. Its fundamental task is to provide judicial bodies with exhaustive and expert information drawn from knowledge of veterinary medicine, in conjunction with applicable laws [8,11].

As in forensic medicine, in veterinary forensic practice it is increasingly often necessary to determine the approximate time of death of an animal. When the time of death of an animal cannot be determined on the basis of medical history, it is necessary to analyse the dynamics of changes in signs of death. In veterinary medicine the time of death is determined using methods based on temperature measurements and evaluation of post-mortem changes. The internal temperature of animals is measured in the rectum and is currently one of the objective methods for determining the time of death [12,13].

The vast majority of veterinary cases involving the need to determine the approximate time of death of an animal deal with the death of dogs, cats or free-living animals. In our study we hypothesized that the decrease in temperature from the time of death depends on the site of the measurement and on the body weight of the animal. No studies were found in the literature enabling the practical use of the kidneys as a site for measuring temperature in order to determine the time of death of dogs. This was the motivation for preliminary research aimed at analysing the rate of decrease in temperature in the kidneys, which would enable a precise determination of the time of death of animals, particularly in the initial period after death.

\section{MATERIAL AND METHODS}

Twelve carcasses of dogs aged from 7 to 16 years were examined. The body weight of the dogs ranged from $4.5 \mathrm{~kg}$ to $30 \mathrm{~kg}$. The animals were divided into two groups according to body weight. The first consisted of small dogs (up to $10 \mathrm{~kg}$ ) and included 6 individuals, and the second group comprised large dogs (over $10 \mathrm{~kg}$ ) and also included 6 individuals. The animals had been euthanized due to advanced age-related health problems or generalized cancer. Only cases in which the time of death could 
be precisely and unquestionably determined on the basis of medical history were included in the study.

The animal carcasses were stored in a room where the temperature, humidity and air flow were continuously measured. The results were recorded every 10 min using an anemometer (Airflow TA-440A). The physical parameters of the air, which were constant over the entire period of the study, were as follows: temperature $18^{\circ} \mathrm{C}$, relative humidity $65 \%$ and mean air flow $0.1 \mathrm{~m} / \mathrm{s}$.

The temperatures in the kidney and the rectum were measured every half hour for 12 hours from the time of death. A measuring probe was inserted into the rectum to a depth of $4 \mathrm{~cm}$, and a probe was introduced into the kidney under ultrasound monitoring (Fig. 1). The dog carcasses were not dissected. The first measurement of internal temperature was made at the time of euthanasia. Temperature was measured with a TERMIO-25P electronic thermometer with accuracy of $\pm 0.01^{\circ} \mathrm{C}$ in conjunction with a $4 \mathrm{~mm} \times 120 \mathrm{~mm}$ ST-02 temperature probe (Termoprodukt, Poland). The data obtained were analysed statistically with Microsoft Excel software using procedures in Matlab ${ }^{\circledR}$ Software v. 7.14 (The Math Works, Inc., Natick, USA).

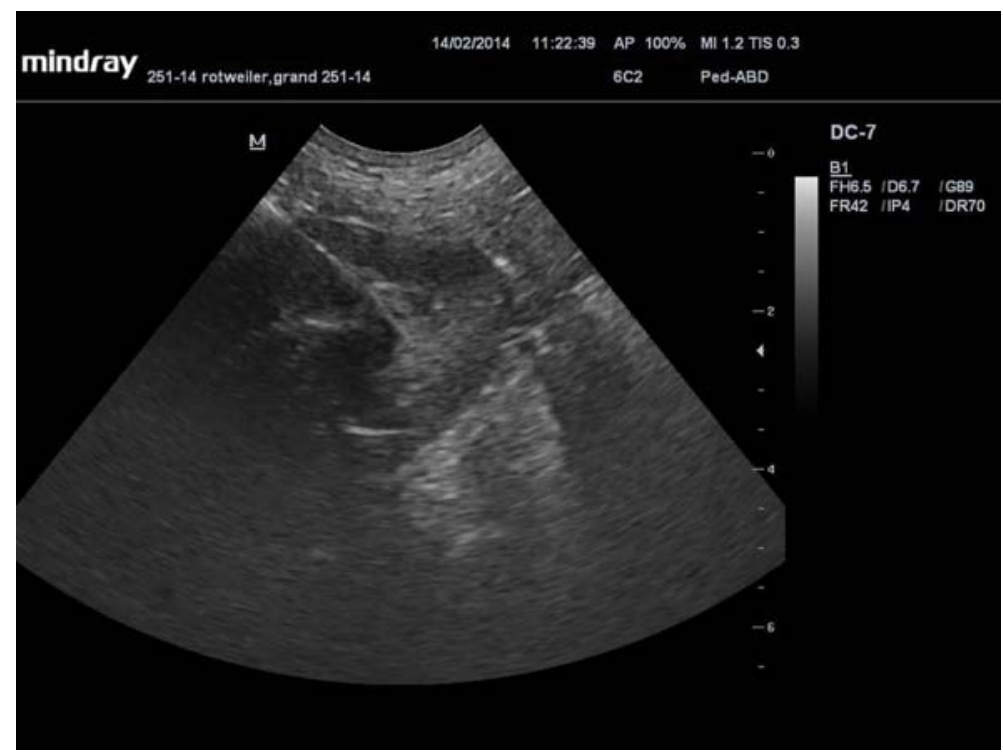

Figure 1. Ultrasound image - kidney with needle probe

\section{RESULTS}

The mean rectal temperature in each of the time intervals in small and large dogs (Table 1) indicates a gradual decrease in temperature over time. At the moment the dogs were euthanized the mean temperature was $38.98^{\circ} \mathrm{C}$. A similar analysis was performed for the temperature measurements in the kidneys (Table 2). At the moment of euthanasia the mean temperature in the kidney was $39.14^{\circ} \mathrm{C}$. 
Table 1. Mean rectal temperature $\left({ }^{\circ} \mathrm{C}\right)$ in the groups of dogs at 30 -minute intervals

\begin{tabular}{|c|c|c|c|c|c|c|}
\hline \multirow{2}{*}{$\begin{array}{c}\text { Time after } \\
\text { euthanasia } \\
{[\mathrm{h}]}\end{array}$} & \multicolumn{2}{|c|}{ Small dogs } & \multicolumn{2}{|c|}{ Large dogs } & \multicolumn{2}{|c|}{ Total } \\
\hline & $\bar{x}$ & SD & $\bar{x}$ & SD & $\bar{x}$ & SD \\
\hline 0 & 38.93 & 0.55 & 39.03 & 0.38 & 38.98 & 0.48 \\
\hline 0.5 & 38.82 & 0.58 & 38.98 & 0.40 & 38.90 & 0.50 \\
\hline 1.0 & 38.10 & 0.87 & 38.38 & 0.55 & 38.24 & 0.74 \\
\hline 1.5 & 37.33 & 1.16 & 37.58 & 0.68 & 37.46 & 0.96 \\
\hline 2.0 & 36.58 & 1.52 & 36.85 & 0.82 & 36.72 & 1.23 \\
\hline 2.5 & 36.02 & 1.79 & 36.12 & 0.91 & 36.07 & 1.42 \\
\hline 3.0 & 35.50 & 1.81 & 35.52 & 1.02 & 35.51 & 1.47 \\
\hline 3.5 & 35.20 & 1.91 & 34.97 & 1.12 & 35.08 & 1.57 \\
\hline 4.0 & 34.87 & 1.79 & 34.42 & 1.21 & 34.64 & 1.55 \\
\hline 4.5 & 34.38 & 1.99 & 34.02 & 1.31 & 34.20 & 1.69 \\
\hline 5.0 & 33.75 & 2.11 & 33.63 & 1.42 & 33.69 & 1.80 \\
\hline 5.5 & 33.17 & 2.49 & 33.18 & 1.50 & 33.18 & 2.06 \\
\hline 6.0 & 32.73 & 2.84 & 32.93 & 1.77 & 32.83 & 2.24 \\
\hline 6.5 & 32.23 & 2.85 & 32.45 & 1.75 & 32.34 & 2.37 \\
\hline 7.0 & 31.78 & 2.85 & 31.98 & 1.82 & 31.88 & 2.39 \\
\hline 7.5 & 31.18 & 3.00 & 31.60 & 1.94 & 31.39 & 2.53 \\
\hline 8.0 & 30.60 & 2.92 & 31.07 & 2.13 & 30.83 & 2.57 \\
\hline 8.5 & 30.10 & 3.14 & 30.62 & 2.19 & 30.36 & 2.72 \\
\hline 9.0 & 29.68 & 3.08 & 30.07 & 2.31 & 29.88 & 2.73 \\
\hline 9.5 & 29.15 & 3.29 & 29.62 & 2.29 & 29.38 & 2.84 \\
\hline 10.0 & 28.80 & 2.98 & 29.32 & 2.42 & 29.06 & 2.72 \\
\hline 10.5 & 28.22 & 3.04 & 28.67 & 2.27 & 28.44 & 2.69 \\
\hline 11.0 & 27.80 & 3.09 & 28.15 & 2.26 & 27.98 & 2.71 \\
\hline 11.5 & 27.15 & 3.15 & 27.67 & 2.18 & 27.41 & 2.72 \\
\hline 12.0 & 26.68 & 3.19 & 27.10 & 2.21 & 26.89 & 2.75 \\
\hline
\end{tabular}

Table 2. Mean kidney temperature $\left({ }^{\circ} \mathrm{C}\right)$ in the groups of dogs at 30 -minute intervals

\begin{tabular}{ccccccc}
\hline $\begin{array}{c}\text { Time after } \\
\text { euthanasia }\end{array}$ & \multicolumn{2}{c}{ Small dogs } & \multicolumn{2}{c}{ Large dogs } & \multicolumn{2}{c}{ Total } \\
\hline$[\mathbf{h}]$ & $\bar{x}$ & SD & $\overline{\bar{x}}$ & SD & $\overline{\bar{x}}$ & SD \\
\hline 0 & 39.10 & 0.48 & 39.18 & 0.44 & 39.14 & 0.48 \\
\hline 0.5 & 38.62 & 0.54 & 39.07 & 0.49 & 38.84 & 0.58 \\
1.0 & 37.98 & 0.78 & 38.53 & 0.68 & 38.26 & 0.82 \\
1.5 & 37.42 & 0.95 & 37.92 & 0.40 & 37.67 & 0.82 \\
2.0 & 36.87 & 0.98 & 37.52 & 0.77 & 37.19 & 0.98 \\
\hline .5 & 36.27 & 1.08 & 36.87 & 0.79 & 36.57 & 1.04 \\
3.0 & 35.68 & 1.09 & 36.25 & 0.77 & 35.97 & 1.03 \\
\hline .5 & 35.42 & 1.00 & 35.87 & 0.91 & 35.64 & 1.03 \\
4.0 & 34.72 & 1.04 & 35.40 & 1.01 & 35.06 & 1.12 \\
4.5 & 34.22 & 1.14 & 34.68 & 0.93 & 34.45 & 1.11 \\
5.0 & 33.78 & 1.09 & 34.35 & 0.86 & 34.07 & 1.07 \\
\hline .5 & 33.37 & 1.11 & 34.05 & 0.71 & 33.71 & 1.04 \\
6.0 & 32.42 & 1.57 & 33.68 & 0.75 & 33.05 & 1.46 \\
6.5 & 31.82 & 1.74 & 33.43 & 0.84 & 32.63 & 1.66 \\
7.0 & 31.25 & 1.77 & 33.05 & 0.71 & 32.15 & 1.70 \\
7.5 & 30.67 & 1.75 & 32.52 & 0.98 & 31.59 & 1.76 \\
8.0 & 30.17 & 1.62 & 32.15 & 1.05 & 31.16 & 1.75 \\
\hline 8.5 & 29.53 & 1.74 & 31.68 & 1.03 & 30.61 & 1.86 \\
9.0 & 29.13 & 1.66 & 31.18 & 1.06 & 30.16 & 1.79 \\
\hline .5 & 28.63 & 1.68 & 30.73 & 1.11 & 29.68 & 1.84 \\
10.0 & 28.10 & 1.65 & 30.40 & 1.18 & 29.25 & 1.90 \\
\hline 10.5 & 27.38 & 1.35 & 29.77 & 1.34 & 28.58 & 1.84 \\
11.0 & 26.88 & 1.34 & 29.13 & 1.13 & 28.01 & 1.72 \\
11.5 & 26.33 & 1.27 & 28.65 & 1.12 & 27.49 & 1.71 \\
12.0 & 25.90 & 1.15 & 28.18 & 1.09 & 27.04 & 1.64 \\
\hline
\end{tabular}


The mean temperature in the rectum and kidney of large dogs was higher than in the group of small dogs in each of the time intervals (Fig. 2). In these dogs the higher temperature in the kidney persisted for the entire study period.

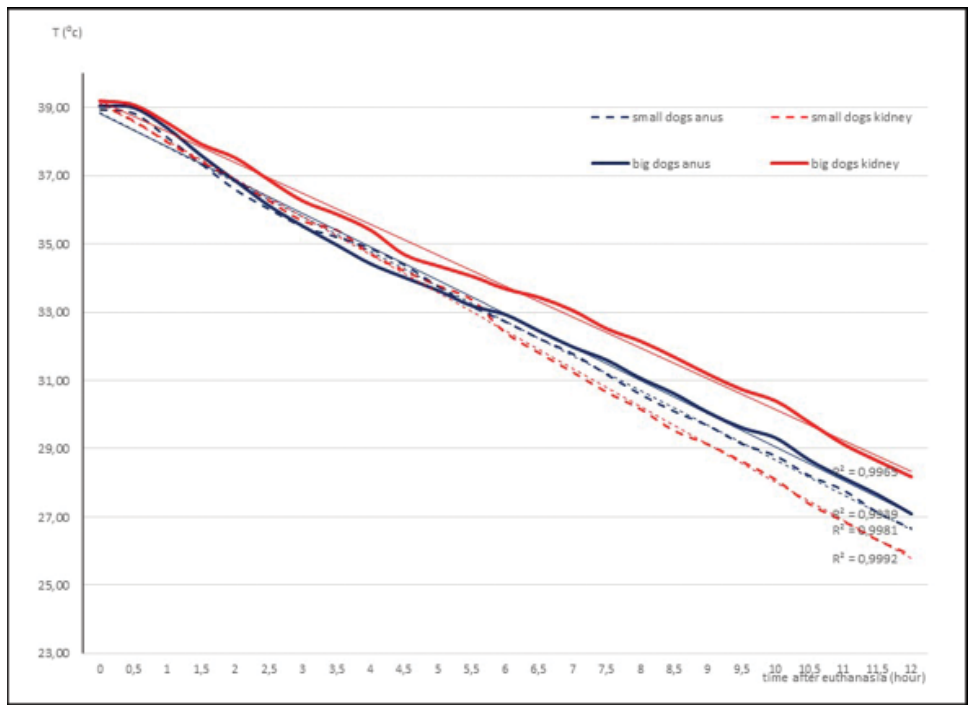

Figure 2. Mean rectal and kidney temperature in the groups of small and large dogs

A comparative analysis was performed between the mean temperature differences in the kidney $\mathrm{T}_{\mathrm{k}}$ and rectum $\mathrm{T}_{\mathrm{a}}$ in small and large dogs (Fig. 3). A greater temperature amplitude was observed in the small dogs for both the kidney and the rectum. The greatest decrease in temperature, $1.2^{\circ} \mathrm{C}$, was noted for the kidney in small dogs between 4 and 6 hours after death.

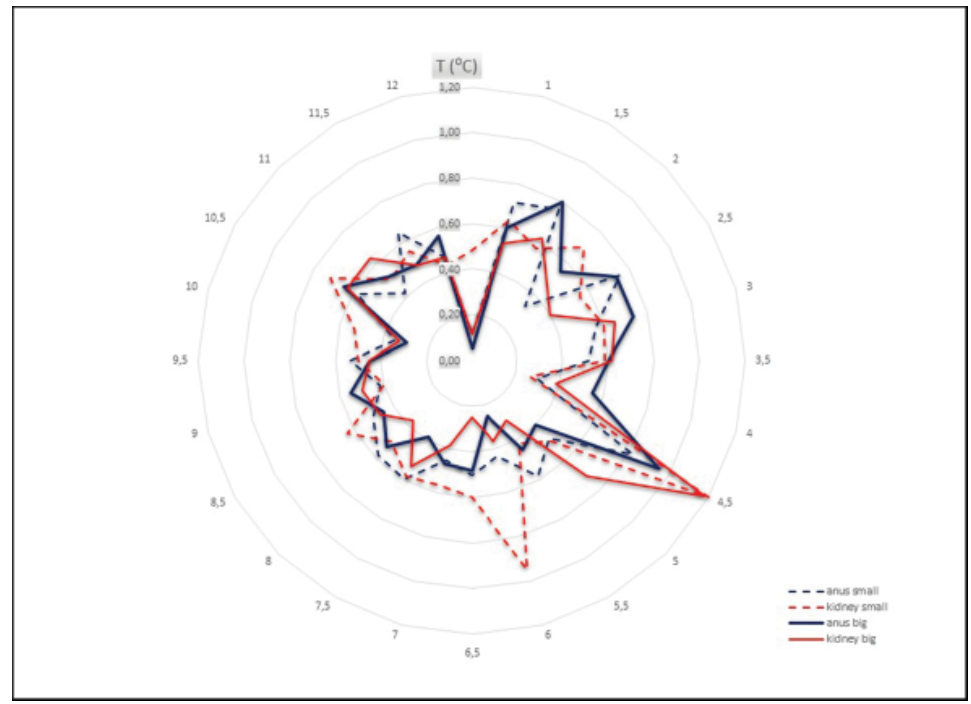

Figure 3. Difference in rectal and kidney temperatures in the groups of small and large dogs at 30-minute intervals 
An analysis was also performed of the dynamics of the decrease in temperature in the kidney and rectum for both groups combined and the difference in temperature between the kidney and rectum in the time intervals studied (Fig. 4). In the first two hours of measurement the difference in temperature between the kidney and rectum did not exceed $0.5^{\circ} \mathrm{C}$, but after this time the rectal temperature decreased considerably faster than the temperature in the kidney. Two hours after death the difference in temperature between the two measurement sites was about $0.5^{\circ} \mathrm{C}$, after which time it dropped below $0.5^{\circ} \mathrm{C}$ (trend line $\mathrm{R}=0.0026$ ).

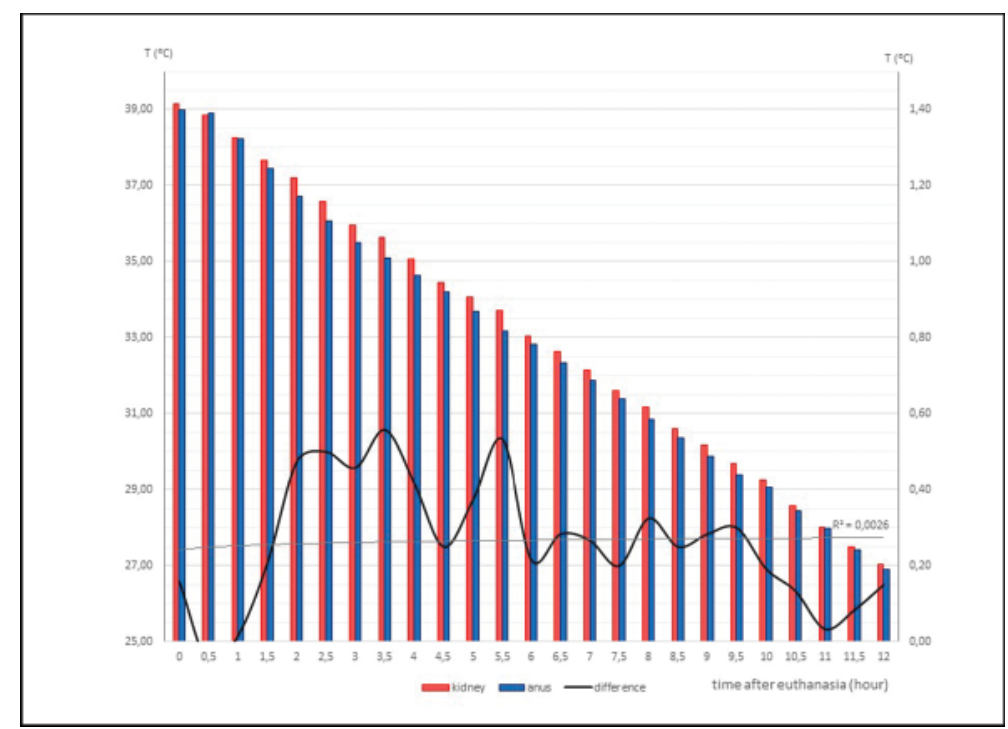

Figure 4. Mean temperature and differences in temperature between the kidney and rectum

\section{DISCUSSION}

Commonly recognized methods for the determination of the time of death can be divided into two groups. One of these includes methods based on the evaluation of post-mortem processes taking place in the carcass. The other consists of methods based on a careful analysis of the process of cooling of the body, involving temperature measurements. These measurements are made in different parts of the body and are considered more precise than the first type of method, particularly in the initial period (up to $18 \mathrm{~h}$ ) after death. The temperature measured in the kidney, brain or eye is more precise than the rectal temperature.

Methods exploiting evaluation of changes taking place after death mainly include parameters of importance in the first 24 hours after death (the degree of development of rigor mortis or changes in lividity, drying out of the cornea and evaluation of the response of the skeletal muscles to an electrical or mechanical stimulus). In the later period after death, time of death can be evaluated on the basis of the degree 
of advancement of late changes, i.e. putrefaction and saponification. Cases in which the carcass is skeletonized are more problematic, as the time of death can only be determined by analysing data pertaining to the fragility, weight and appearance of the bones. In these cases a method which enables quantitative determination of amino acids in the bones or ultraviolet fluorescence is used. In the case of remains that are at least a few centuries old, measurements of $\mathrm{C}^{14}$ activity are used, generally in other areas of science, such as archaeology [14-16]. Biochemical methods testing the activity of enzymes in tissues and systemic fluids and the level of organic and inorganic compounds are used as well. Forensic entomology, which is gaining in importance, involves detecting the presence of larvae and insects on the body and determining their stage of development $[13,17]$. One of the latest new achievements is proton magnetic resonance spectroscopy (H-MRS), used to identify substances arising from the decomposition of brain tissue. It enables determination of time of death during an interval between 30 to $400 \mathrm{~h}$ [18]. Research continues to be conducted on the use of the degree of DNA decomposition to determine the time of death. The degree of DNA decomposition can be evaluated using flow cytometry. This is an experimental method which currently has not found broader application in analyses carried out for veterinary forensic purposes. Attempts are also being made to analyse the electrical resistance of tissues to determine the time of death up to the twentieth day after death [19]. The least precise methods include those evaluating the level of chlorides in the blood plasma, the potassium concentration in the vitreous body of the eye, or examination of the cerebrospinal fluid and synovial fluid [20,21]. Methods based on analysis body cooling, involving measurement of the temperature in various parts of the body (temperature-based methods) are considered to be more precise than methods based on evaluation of post-mortem changes taking place in the body, particularly in the initial period after death (up to about $20 \mathrm{~h}$ ) [22,23]. The first scientific reports regarding the decline in body temperature after death date back to the 19th century, and the first of these was a study by Rainy in 1868. The author made several accurate observations, most of which remain valid today. He stated that measurements of the surface temperature of the body have little value for determining the time of death, and may be of no use when the ambient temperature is variable, while repeated measurements of the temperature enable calculations that may only suggest a time interval in which death occurred. The author was the first to propose an algorithm, which was further used in the studies conducted in the subsequent years. Single measurement points including the liver, rectum and brain, as well as multi-point measurements including about a dozen different areas of the body were analysed.

Comparative analysis of the temperature measured after death in different organs showed that the temperature in the liver is similar to the rectal temperature. In the recent years, researchers turned their attention to the decrease in temperature in the brain and found that the time and temperature curve for the brain was the most regular, and that determination of time of death was most reliable up to 24 $\mathrm{h}$ after death. Relatively high precision is also observed when body temperature is 
reduced to the point that it is only slightly different from the ambient temperature. A breakthrough was the concept of using measurements taken twice at a certain time interval. The method was based on the standardization of the decrease in temperature and adoption of the hypothesis that it is 0 at the moment of death and 1 after the cooling period. In this case the percentage difference was the decrease from the physiological temperature of $37^{\circ} \mathrm{C}$ to ambient temperature. During many experiments, a flaw in this method was associated with the need to measure the temperature of the body at least twice with a significant time interval. It was assumed here that the body is not moved and the ambient temperature from the moment of death to the time when the measurements are completed does not change. Further studies also presented a thermodynamic model of an infinitely long cylinder as an experimental model of the human body. Mathematical measurements proved that the radius of the body may be one of the most important elements defining the cooling curve, while additional elements associated with thermal isolation, such as clothing or various types of covering on the body, are less significant. Attention also turned to lipid tissue, and it was found that the slow cooling of the body in the initial period was not dependent on the thermal isolation properties of lipid tissue but linked only to its increased volume. As a result of this process the radius of the body increases. By describing this function it is possible to determine the temperature gradient, as well as the influence of extreme conditions on the cooling process. The slower decline in temperature in the initial period is linked to the influence of surface tissues of the body with limited heat conductivity and to heat production, as well as to tissue metabolism immediately after death. A confirmation of previously conducted research was the formulation of the concept of a plateau, where it was found that each method for determining the time of death must take into account the initial slower decrease in body temperature. Research conducted in the 1970s and 1980s led to the development of a bi-exponential model that was continually modified [24]. Here we have presented a simplified method for determining the cooling coefficient, where statistical values were determined for the deviation between the calculated and actual time of death in the cooling process in standardized conditions. Suitable nomograms (Figure 5), have now been developed which have broad applications and allow time of death to be easily determined and not only estimated $[25,26]$. The bi-exponential model finds application, for example, in cases of a single temperature measurement in the rectum, taking into account the ambient temperature in standardized cooling conditions. There is also a method employing a cooling curve which involves measurement of the ambient temperature and two measurements of rectal temperature at an interval of 1 h. The time which passed since the moment of death is calculated on the basis of the value of a coefficient used in a graph presenting the cooling curve. This is a method based on numerical analysis of the equation of the flow of heat through a cylinder. A certain inconvenience in this case is the fact that the solution to differential equations takes the form of an infinite sum, which means that in practice it is not possible to use analytical solutions, but only their numerical approximations. Research conducted on human corpses and on rabbits show that the rectum is not located on the axis of 
the body but at $3 / 4$ of the length of its diameter. The values for the heat conductivity coefficient have also been determined for different tissues [27].

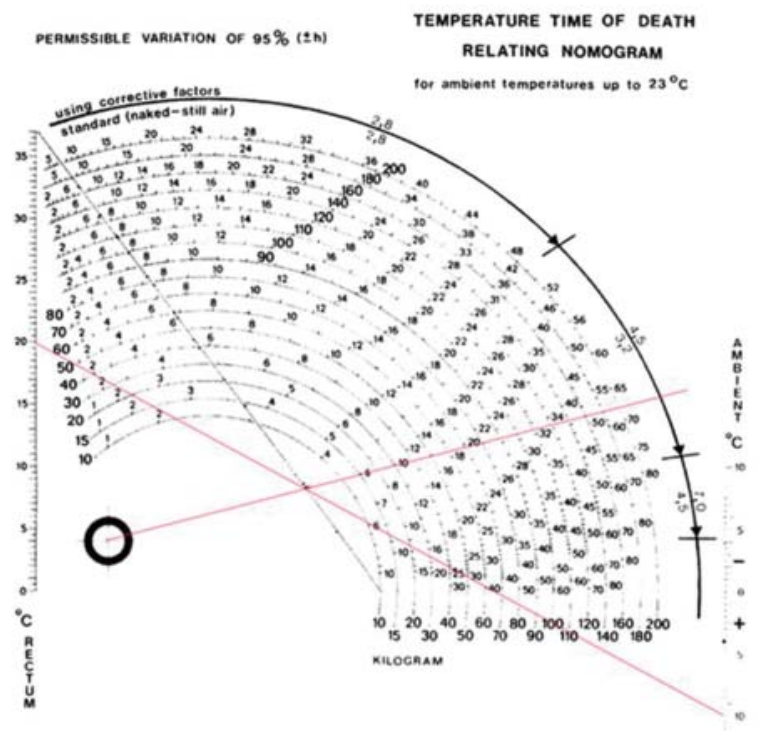

Figure 5. Nomogram for reading the time of death on the basis of a single temperature measurement in the rectum, including body weight and ambient temperature below $23^{\circ} \mathrm{C}$ (Henssge, 1988)

The results of our study show that a very slow decrease in temperature persists up to $30 \mathrm{~min}$ after death. Considerable dynamics was observed in the decrease in kidney temperature in the group of small dogs with body weight up to $10 \mathrm{~kg}$. The plateau effect in the kidney occurs only in dogs with body weight up to $10 \mathrm{~kg}$ in a period up to $30 \mathrm{~min}$ from the time of death. The next plateau effect was observed in the time interval between $3 \mathrm{~h}$ and $3.5 \mathrm{~h}$ after death. The dynamics of the decrease in rectal temperature in the group of dogs with low body weight, i.e. up to $10 \mathrm{~kg}$, and in the group of dogs with high body weight, i.e. $10-48 \mathrm{~kg}$, were similar over the entire study period. The occurrence of a second plateau effect in the deeper located organ in comparison with the rectum is interesting and should be studied further. Comparisons should also be made to establish whether a similar phenomenon takes place in other, deeper-placed organs and whether the body weight of the dogs has any effect on the occurrence of a second plateau effect. Research should also be conducted in other deeply situated internal organs in order to confirm or rule out the occurrence of a second or subsequent plateau effects depending on the body weight of dogs. The possibility of an influence of the depth at which the probe is introduced in each of the organs on the possibility of successive plateau effects should be investigated as well. In the case of occurrence of successive plateau effects it would be useful to develop mathematical formulas for each organ. 
There are other organs which are used to determine body temperature. These include the brain, where a highly precise measurement is obtained in the first $6 \mathrm{~h}$ after death $[28,29]$. A significant factor in the case of the brain is that the weight of the body has no effect on its temperature. This type of research has not yet been performed on dogs and cats and applied in veterinary jurisprudence, so it cannot be definitively stated whether the density and length of the hair coat of the skull have any effect on thermal isolation of the brain. In the case of human corpses a decisive role is ascribed to different amounts of hair and types of head covering, including the type of material it is made from and its chemical composition. A significant factor creating some difficulty for the use of temperature measurements in human and animal brains is the need to insert the measuring probe to the proper depth in the cranial cavity. Other authors also report that up to $6.5 \mathrm{~h}$ after death the most reliable results can be obtained by taking the temperature in the brain. Between $6.5 \mathrm{~h}$ and $10.5 \mathrm{~h}$ after death temperature measurements should be made in both the rectum and the brain, but after $10.5 \mathrm{~h}$ only in the rectum [30]. Typical bi-exponential curves with a very brief plateau period were obtained in the case of the temperature in the brain, and exponential curves for the measurements of the peripheral parts. Comparison of both types of curve showed high repeatability. Interesting research has been carried out on the eyeball and the orbital soft tissues in animals. The research confirmed the lack of a plateau effect. It was established that in the case of the use of the eyeball the most reliable results can be obtained during the period up to $13 \mathrm{~h}$ after death, whereas in the case of the temperature of the orbital soft tissues the greatest precision is obtained up to $10.5 \mathrm{~h}$ after death [31]. This study also found no plateau in the decrease in temperature in the case of the orbital tissues and eyeballs. It was demonstrated that low air flow in the room, up to 2 on the Beaufort scale, i.e. the equivalent of a light breeze, does not in any way affect the coefficient of the constant rate of the decrease in temperature or the post-mortem process of cooling of the body. It was established that the presumed air flow velocity where the body was found cannot be used for a precise estimate of time of death, whereas the actual air flow velocity where the examination is performed is indispensable. The main factor determining the rate of cooling of the body is the ambient temperature.

\section{Acknowledgements}

The authors would like to thank Agnieszka Panecka M.Sc. of the Faculty of Biology and Animal Breeding, University of Life Sciences in Lublin, Lublin, Poland for assisting with the preparation of the experiment.

\section{Authors' contributions}

PL authorship of the research hypothesis, a lead role in planning the experiment, the choice of animal material for the research, collection of data necessary for the 
statistical analysis. MG, JP, GT, GB, WC, ZNP and WL participated in analysis of the results and preparation of the manuscript for publication.

\section{Declaration of conflicting interests}

The author(s) declared no potential conflicts of interest with respect to the research, authorship, and/or publication of this article.

\section{REFERENCE}

1. Banka K, Buszewicz G, Listos P, Madro R: Usefulness of GC-MS method for the determination of DDT, DMDT, and gamma-HCH in bees (bodies) for legal purposes. Bull Vet Inst Pulawy 2010, 54:655-659.

2. Raszeja S: Dziś i jutro tanatologii sądowo-lekarskiej. Arch Med Sąd i Krym 2007, 42:420426.

3. Jaegermann K, Widacki J: Zmiany paradygmatu medycyny sądowej i kryminalistyki. Arch Med Sąd i Krym 1986, 36: 85-90.

4. Raszeja S, Śliwka K: Ustalanie czasu śmierci w świetle piśmiennictwa rodzimego. Arch Med Sąd i Krym 1986, 36: 91-100.

5. Berent J: Ustalanie czasu zgonu na podstawie pomiarów temperatury. Część I. Od pierwszych badań z dziewiętnastego wieku do koncepcji opartej na modelu dwuwykładniczym Marshalla-Hoare. Arch Med Sąd i Krym 2005, 55:209-214.

6. Kaliszan M, Hauser R: Określanie czasu zgonu na podstawie pomiaru temperatury oka wobec innych miejsc ciała. Arch Med Sąd i Krym 2007, 57:399-405.

7. Lutyński S: Administracja weterynaryjna i weterynaria sądowa. Państwowe Wydawnictwo Rolnicze i Leśne. Warszawa. 1989, 260-283.

8. Michalski Z: Weterynaria sądowa. Skrypty Akademii Rolniczej we Wrocławiu nr 387. Wydawnictwo Akademii Rolniczej we Wrocławiu. Wrocław. 1993.

9. Szarek J, Przeździecka D, Babińska I, Sobczak-Filipiak M, Truszczyńska M: Weterynaria Sądowa - przewodnik do ćwiczeń. Wydawnictwo Uniwersytetu Warmińsko - Mazurskiego. Olsztyn. 2003.

10. Nozdryn-Plotnicki Z, Listos P, Lopuszyski W, Debiak P: Section investigation of animals wounded from fire arms: some remarks. Med Weter 2005, 61:887-889.

11. Żuliński T: Weterynaria sądowa. Wyższa Szkoła Rolnicza, Lublin.1968, 9-12.

12. Listos P, Nozdryn-Płotnicki Z, Piórkowski J, Sokołowski A: Post mortem estimation the time of death using the measurements of the rectal temperature in comparison with the temperature in muscles. Procedings of the XV Meeting of Polish Society of Forensic Medicine and Kryminology. 2010, 40.

13. Campobasso CP, Linville JG, Wells JD: Forensic genetic analysis of insect gut content. Am J Forensic Med Pathol 2005, 26:161-165.

14. DiMaio VJ, DiMaio D: Ustalanie czasu śmierci. In: Medycyna sądowa. Urban \& Partner, Wrocław 2003. 
15. Raszeja S, Nasiłowski W, Markiewicz J: Medycyna sądowa. Podręcznik dla studentów. PZWL, Warszawa 1993.

16. Saukko P, Knight B: Knight's forensic pathology. Arnold. London 2004, 52-97.

17. Clark K, Evans L, Wall R: Growth rates of the blowfly, Lucilia sericata, on different body tissues. Forensic Sci Int 2006, 156:145-149.

18. Scheurer E, Itch M, Dietrich R: Statistical evaluation of time-dependent metabolite concentrations: estimation of postmortem intervals based on in situ 1H MRS of the brain. NMR Biomed 2005,18:163-172.

19. Qerido D, Philips MR: Estimation of postmortem interval. Temperature - correction of extracellular abdominal impedance during the first 21 days of death. Forensic Sci Int 2001, 116:133-138.

20. Balasooriya BAW, Hill CAS, Williams AR: The biochemistry of vitreous humor. A comparative study of the potassium, sodium and urate concentrations in the eyes in identical time intervals after death. Forensic Sci Int 1984, 26:85-91.

21. Madea B: Is there recent progress in the estimation of the postmortem interval by means of thanatochemistry? Forensic Sci Int 2005, 151:139-149.

22. Knight B: The estimation of the time since death in the early postmortem period. Arnold. London. 2002, 3-42.

23. Henssge C, Madea B: Estimation of the time since death in the early post-mortem period. Forensic Sci Int 2004, 144:167-175.

24. Henssge C: Death time estimation in case work. I. The rectal temperature time of death nomogram. Forensic Sci Int 1988, 38:209-236.

25. Henssge C, Althaus L, Bolt J: Experiences with a compound method for estimating the time since death. I. Rectal temperature nomogram for time since death. International J Legal Med 2000,113: 303-319.

26. Henssge C, Madea B.: Estimation of the time Since Heath in the early post-mortem period. Forensic Sci Int 2004, 144:123-133.

27. Kuroda F, Hiraiwa K, Oshida S, Akaishi S: Estimation of postmortem interval from rectal temperature by use of computer (IV) - Thermal diffusivity of the rabbit. Med Sci Law 1983, 23:125-130.

28. Henssge C, Beckmann ER, Wischhusen F: Nomographische Bestimmung der Todeszeit durch Messung der Hirntemperatur. Beitrage Gerichtige Medizin 1984, 42:107-111.

29. Henssge C, Beckmann ER, Wischhusen F: Determination of the time of death by measurement of central brain temperature. Zeitschrift für Rechtsmedizin 1985, 93:1-22.

30. Henssge C, Frekers R, Reinchardt S, Beckmann ER: Todeszeit-bestimmung auf der Basis simultaner Messung von Hirn und Rectal temperature. Z. Rechtsmed. 1984, 93:123-133.

31. Kaliszan M, Hauser R, Kaliszan R, Wiczling P, Buczynski J, Penkowski M: Verification of the exponential model of body temperature decrease after death in pigs. Experimental Physiology 2005, 90:727-738. 


\title{
POSTMORTALNA PROCENA VREMENA UGINUĆA PASA ZASNOVANA NA UPOREDNOM MERENJU TEMPERATURE BUBREGA I REKTALNE TEMPERATURE
}

\author{
LISTOS Piotr, GRYZINSKA Magdalena, PIORKOWSKI Jacek, TERESINSKI \\ Grzegorz, BUSZEWICZ Grzegorz, CHAGOWSKI Wojciech, NOZDRYN- \\ PLOTNICKI Zbigniew, LOPUSZYNSKI Wojciech
}

Obavljena je studija u okviru koje su psi podeljeni na osnovu telesne mase u dve grupe: do $10 \mathrm{~kg}$ i od 10 do $30 \mathrm{~kg}$. Cilj studije je bio da se odredi dinamika postmortalnog snižavanja temperature u rektumu i u bubrezima. Temperature su merene na oba situsa istovremeno, upotrebom termometra koji je bio povezan sa računarom uz stalne uslove spoljašnje sredine (obdukcione sale). Kod oglednih životinja, uočena je povećana temperatura u bubrezima tokom obavljanja studije. Uporedna analiza razlika između srednjih vrednosti temperatura u bubrezima i rektumu kod malih i velikih pasa pokazala je da postoji najveća amplituda u grupi malih pasa i to kako u bubrezima tako i u rektumu. Najveće smanjenje u temperaturi $1,2^{\circ} \mathrm{C}$, bilo je uočeno u bubrezima malih rasa pasa u periodu od 4 do 6 sati posle uginuća. Analiza dinamike smanjenja temperature u bubrezima i rektumu, za obe grupe pasa kao i razlike u temperaturama između bubrega i rektuma u analiziranim vremenskim intervalima, pokazala je da $\mathrm{u}$ prva dva sata posle uginuća, razlika u temperaturama nije prelazila $0,5^{\circ} \mathrm{C}$. Dva sata posle uginuća, razlike u temperaturama bubrega i rektalne temperature bile su oko $0,5^{\circ} \mathrm{C}$. Posle dva sata od uginuća, razlike su bile manje od $0,5^{\circ} \mathrm{C}$. 